\title{
Synthesis of Photochromic AgCl-Urethane Resin Composite Films
}

\author{
Hidetoshi Miyazaki, ${ }^{1}$ Hirochi Shimoguchi, ${ }^{1}$ Hisao Suzuki, ${ }^{2}$ and Toshitaka Ota ${ }^{3}$ \\ ${ }^{1}$ Shimane University, 1060 Nishikawatsu, Matsue, Shimane 690-8504, Japan \\ ${ }^{2}$ Shizuoka University, 3-5-1 Johoku Nakaku, Hamamatsu, Shizuoka 432-8561, Japan \\ ${ }^{3}$ Nagoya Institute of Technology, 10-6-29 Asahigaoka, Tajimi, Gifu 507-0071, Japan \\ Correspondence should be addressed to Hidetoshi Miyazaki, miya@riko.shimane-u.ac.jp
}

Received 21 July 2011; Revised 14 November 2011; Accepted 8 December 2011

Academic Editor: Steve Bull

Copyright (๑) 2012 Hidetoshi Miyazaki et al. This is an open access article distributed under the Creative Commons Attribution License, which permits unrestricted use, distribution, and reproduction in any medium, provided the original work is properly cited.

AgCl-resin photochromic composite films were prepared using $\mathrm{AgNO}_{3}, \mathrm{HCl}-\mathrm{EtOH}, \mathrm{CuCl}_{2}$ solution, and a liquid-state urethane resin as starting materials. The obtained composite films showed a photochromic property. The rate of darkening of the composite film increased after mixing with $\mathrm{CuCl}_{2}$. The $\mathrm{AgCl}$ particle size in the film without heat treatment was $6-20 \mathrm{~nm}$, and that of the heat-treated film was $25-80 \mathrm{~nm}$; these results were confirmed using TEM observations. The fading rate of the film without heat treatment was higher than that of the heat-treated films.

\section{Introduction}

A glass substrate doped with silver halide shows a photochromic property $[1,2]$. This phenomenon is effective for controlling the transmittance of solar light through glass win-dows. To form a photochromic glass window, glass is fused at temperatures higher than $1,300-1,500^{\circ} \mathrm{C}$ and shaped. Then the precursor glass must be annealed at $550-700^{\circ} \mathrm{C}$ to deposit silver halide microcrystals from the homogeneous glass. For that reason, it is difficult to produce large flat glass sheets economically. In addition, the resulting photochromic glass is heavy. Consequently, the use of photochromic glasses is limited. However, photochromic materials containing $\mathrm{AgCl}$ nanoparticles have been fabricated not as glasses, but as films [3] and hybrid materials [4].

Previous reports have described studies of light-selective composite films: an ITO-urethane resin IR-opaque composite film [5], a $\mathrm{ZnO}$-urethane resin UV-opaque composite film [6], and a $\mathrm{VO}_{2}$-resin thermochromic composite film [7]. To synthesize a composite film, a fabrication process is advantageous for synthesizing glasses because of its lower temperature process. Furthermore, the resulting composite film is very lightweight. Therefore, the authors attempted to fabricate a photochromic composite film in this study.

In this investigation, a urethane resin was used as a matrix, with $\mathrm{AgNO}_{3}$ and $\mathrm{HCl}$-ethanol used as fillers, and $\mathrm{AgCl}$ urethane resin photochromic composites fabricated using these starting materials. Liquid type urethane resin shows a photocuring property, and the cured urethane resin shows high transmittance at the visible wavelength region. The photochromic property of the resulting composite films was evaluated. Then, using $\mathrm{Cu}$ (the source of $\mathrm{CuCl}_{2}$ ) as a sensitizer, a composite film was synthesized. The photochromic property of the composite was investigated with and without the $\mathrm{Cu}$ sensitizer.

\section{Experimental}

$\mathrm{AgNO}_{3}$ (99.5\%; Wako Pure Chemical Industries Ltd., Osaka, Japan), HCl-EtOH (0.1 mol/L; Sigma-Aldrich Japan K. K., Tokyo, Japan), $\mathrm{CuCl}_{2}$ (95\%; Wako Pure Chemical Industries Ltd., Osaka, Japan), and a liquid state urethane resin (M-40, density of $1.15 \mathrm{~g} / \mathrm{cm}^{3}$; Asahi Kasei Chemicals Corp., Tokyo, Japan) were used as starting materials. $\mathrm{AgNO}_{3}$ powder was dissolved into ethanol at a concentration of $0.1 \mathrm{~mol} / \mathrm{L}$, and $\mathrm{CuCl}_{2}$ powder was dissolved into the solution at a $\mathrm{Cu} / \mathrm{Ag}$ ratio of 0.1 . The prepared solution was mixed with a liquid urethane resin, and $\mathrm{HCl}-\mathrm{EtOH}$ solution was added sequentially to the mixture solution. The preparation conditions are presented in Table 1. These mixtures were stirred well. Then the precursor solution was prepared. The mixture was degassed for $30 \mathrm{~min}$. Then the mixture was formed to $1 \mathrm{~mm}$ thickness using slide glasses. The precursor films were cured using UV-light irradiation, thereby producing composite 
TABLE 1: Synthesis conditions of AgCl-resin photochromic composite films.

\begin{tabular}{lccccc}
\hline Sample & Urethane $(\mathrm{g})$ & $\begin{array}{c}\mathrm{AgNO}_{3}-\mathrm{EtOH} \\
(0.1 \mathrm{~mol} / \mathrm{L}, \mathrm{mL})\end{array}$ & $\begin{array}{c}\mathrm{HCl}-\mathrm{EtOH} \\
(0.1 \mathrm{~mol} / \mathrm{L}, \mathrm{mL})\end{array}$ & $\begin{array}{c}\mathrm{CuCl}_{2}-\mathrm{EtOH} \\
(0.1 \mathrm{~mol} / \mathrm{L}, \mathrm{mL})\end{array}$ & Heat treatment \\
\hline 1 & 20 & 1.0 & 1.0 & - & Yes \\
2 & 20 & 1.0 & 1.0 & 0.1 & Yes \\
3 & 20 & 1.0 & 1.0 & 0.1 & No \\
\hline
\end{tabular}

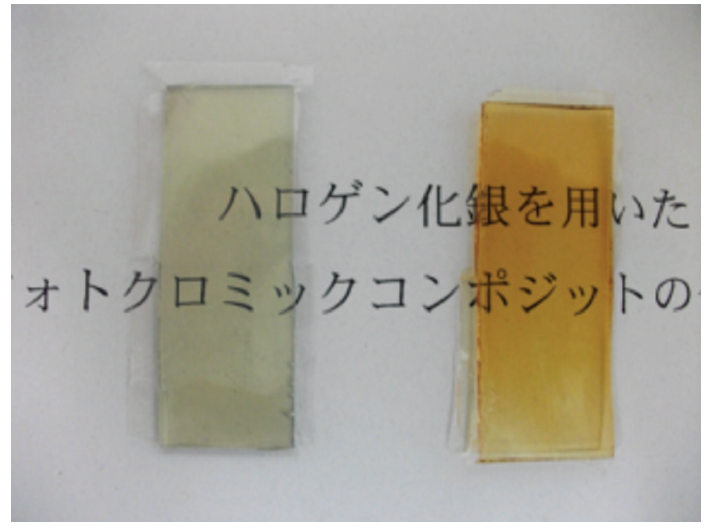

Figure 1: Photographs of composite films (Sample 1 in Table 1) before and after UV irradiation.

films. Furthermore, to confirm heat treatment effects, heat treatment of the composite films was conducted at $120^{\circ} \mathrm{C}$ for 10 min using a hotplate.

Transmittance of the obtained composite film was measured using a spectrophotometer (UV-1600; Shimadzu Corp.) at a wavelength range of $200-1,100 \mathrm{~nm}$. To evaluate the photochromic property, transmittance measurements were conducted using UV-visible light irradiation of the resulting films. The microstructure and the composite film particles were observed using transmission electron microscopy (TEM, EM-002B; Topcon Corp.).

\section{Results and Discussion}

The as-prepared films were brown because the precursor films had been cured by UV-light irradiation and the composite film was colored. The darkened films faded with heat treatment at $120^{\circ} \mathrm{C}$ for $10 \mathrm{~min}$. The resulting transparent films were used to evaluate the photochromic property. The films were irradiated by UV-light and become dark. Then their photochromic properties were observed. Figure 1 presents photographs of the composite films before and after UV irradiation. The fabrication conditions of the sample were those of sample number of " 1 " in Table 1. Hereinafter, sample number " $n$ (integer)" signifies the sample number shown in Table 1. As the photograph shows, the transparent composite film was colored by UV irradiation. Therefore, the resulting composite film shows a photochromic property.

Two composite films were prepared with or without $\mathrm{CuCl}_{2}$ as the sensitizer. The samples were "1" and "2" presented in Table 1. Figure 2(a) shows the dependence of the transmittance on UV-light irradiation time at $420 \mathrm{~nm}$ wavelength. For $10 \mathrm{~min}$ UV irradiation, the transmittance of the composite film without adding $\mathrm{CuCl}_{2}$ (Sample 1) decreased from $50 \%$ to $10 \%$. However, that of the $\mathrm{Cu}$-added film (Sample 2) varied from $50 \%$ to $0 \%$ for $4 \mathrm{~min}$. The rate of darkening of the film containing copper was much higher than that without the $\mathrm{Cu}$-containing film. In general, for photochromic glass, $\mathrm{Cu}_{2} \mathrm{O}$ or $\mathrm{CuO}$ was used as the sensitizer $[2,8]$. However, the photosensitivity rate of the synthesized composite films in this study was increased by mixing $\mathrm{CuCl}_{2}$ as the sensitizer. These results show that $\mathrm{CuCl}_{2}$ is useful as a sensitizer for the preparation of composite films.

Figure 2(b) presents the fading property of the colored composite films. The fading rate of the composite film without added copper was very low: the composite film with copper retained transmittance of $0 \%$ even after 1 month.

Precursor composite films were synthesized with $\mathrm{AgNO}_{3}$, $\mathrm{HCl}-\mathrm{EtOH}$, and $\mathrm{CuCl}_{2}$. To evaluate the heat-treatment effect, a film was prepared without heat treatment (Sample 3 in Table 1). The as-prepared film was faded in a dark room for 1 week. Figure 3 shows the photochromic property of the asprepared and heat-treated films. The darkening properties of both films were very similar, and the transparent films became colored during $10 \mathrm{~min}$ UV irradiation. The transmittance of the colored composite film with heat treatment faded by 10\%-30\% during 1 week, and the no-heating film faded by $10 \%-60 \%$ in 5 days. The fading rate of the film without heat treatment was much higher than that of the film with heat treatment.

Figures 4(a) and 4(b) portray TEM bright field images of as-prepared and heat-treated composite films. The TEM images show that the $\mathrm{AgCl}$ particle size in the as-prepared film was $6-20 \mathrm{~nm}$, and that in the heat-treated film was $25-80 \mathrm{~nm}$. In general, the particle size range of $\mathrm{AgCl}$ in photochromic glasses is $5-30 \mathrm{~nm}$ [8]. The $\mathrm{AgCl}$ particle sizes of the composite films without heat treatment were close to the $\mathrm{AgCl}$ size of the photochromic glasses. Therefore, the coloring and the fading rates of the films without heat treatment were higher than those of the heat-treated films.

\section{Conclusion}

Photochromic composite films were synthesized with silver chloride particles dispersed in a urethane resin matrix using $\mathrm{AgNO}_{3}, \mathrm{HCl}$, and $\mathrm{CuCl}_{2}$ ethanol solutions. The rate of darkening for the film containing $\mathrm{CuCl}_{2}$ was higher than that of films without $\mathrm{CuCl}_{2}$, which shows that $\mathrm{CuCl}_{2}$ in the $\mathrm{AgCl}$ composite film acted as a sensitizer. The rate of fading of the film without heat treatment was higher than that of the heat-treated films. The particle size of the film without heat treatment was $6-20 \mathrm{~nm}$, which is similar to the microcrystal 


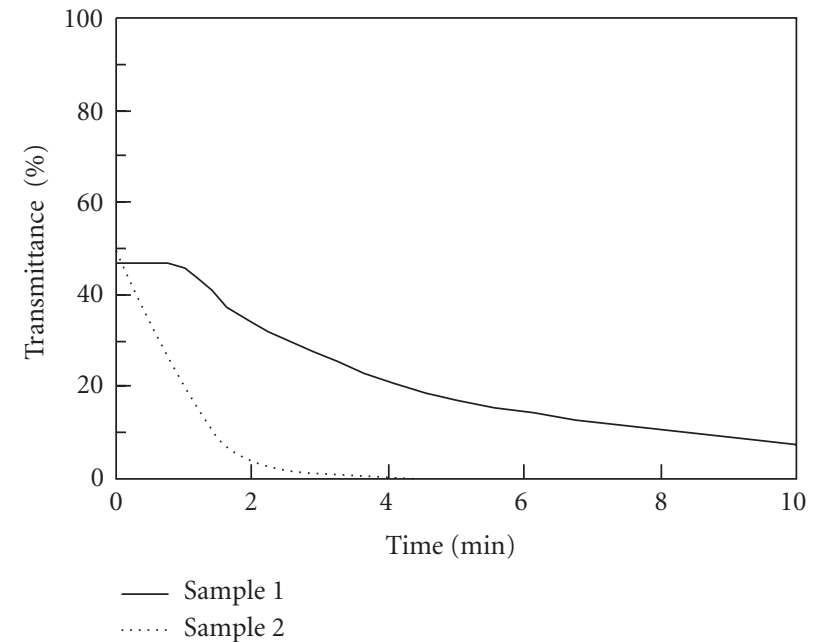

(a)

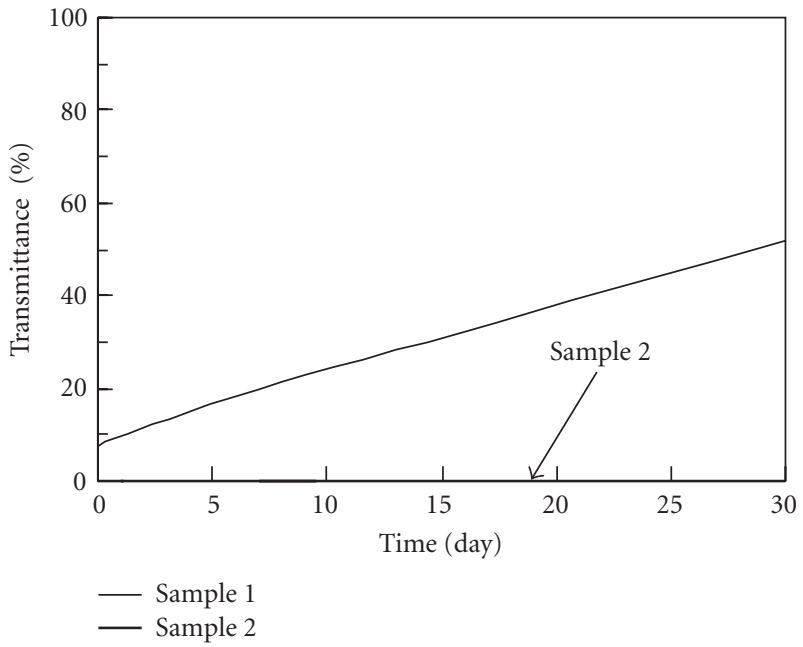

(b)

FIgURE 2: Time dependence of the transmittance of the films with (Sample 2) and without (Sample 1) $\mathrm{CuCl}_{2}$, at $420 \mathrm{~nm}$ wavelength. (a) shows the darkening property. (b) shows the fading property.

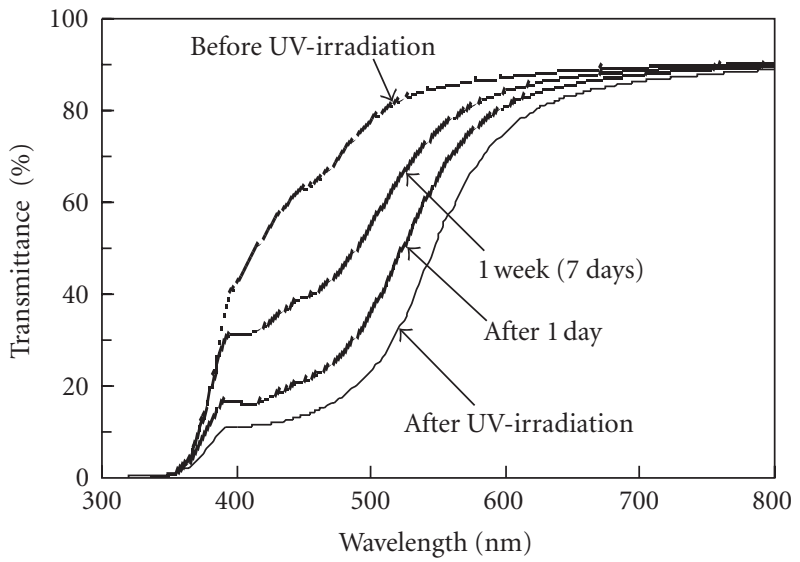

(a)

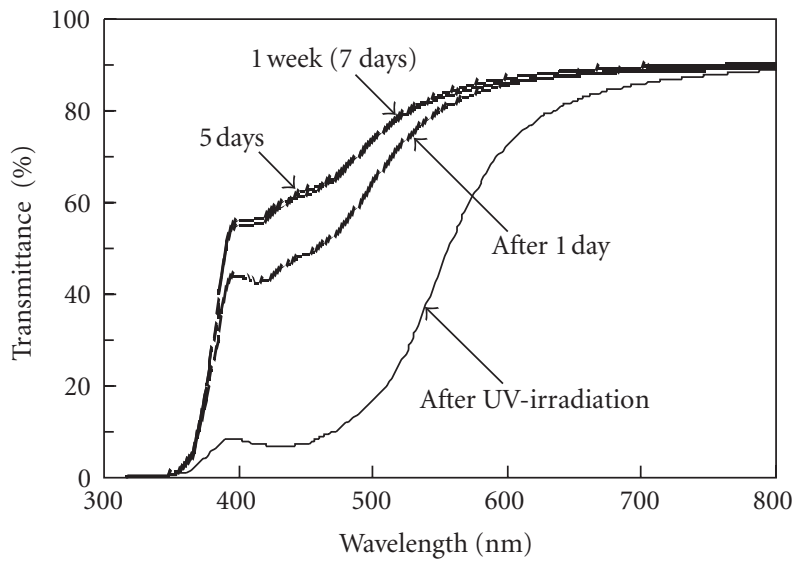

(b)

FIGURE 3: Photochromic property of the (a) heat-treated (Sample 2) film and the (b) as-prepared (Sample 3) film.

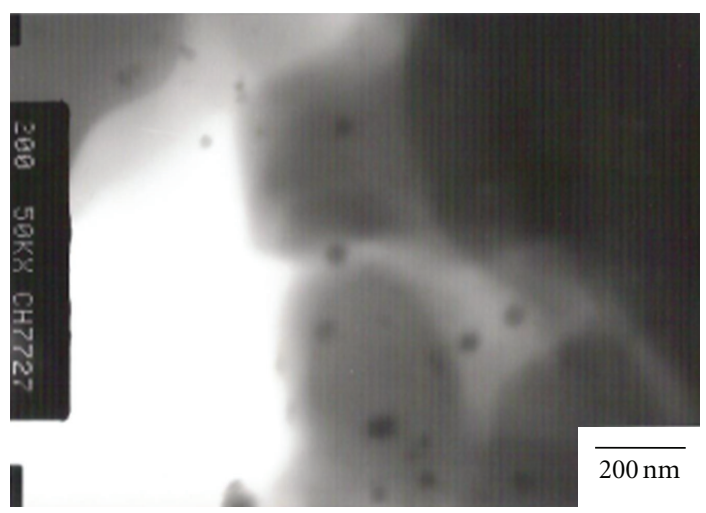

(a)

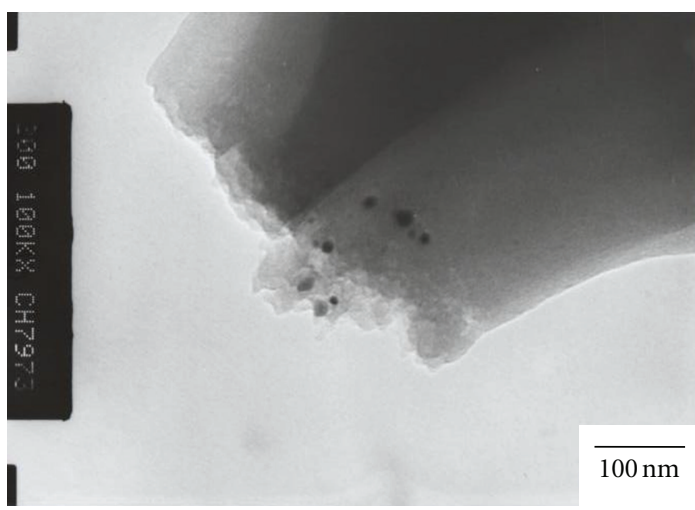

(b)

FIgURE 4: TEM image of (a) the heat-treated (Sample 2) and (b) the as-prepared (Sample 3) films. 
size of the $\mathrm{AgCl}$ photochromic glass. Therefore, it is inferred that the coloring and the fading rates of the films without heat treatment were higher than those of the heat-treated films.

\section{References}

[1] S. L. Kraevskii and V. F. Solinov, "Interface models for the photochromism and thermochromism of glasses with nanocrystals," Journal of Non-Crystalline Solids, vol. 316, no. 2-3, pp. 372-383, 2003.

[2] W. H. Armistead and S. D. Stookey, "Photochromic silicate glasses sensitized by silver halides," Science, vol. 144, no. 3615, pp. 150-154, 1964.

[3] H. Tomonaga and T. Morimoto, "Photochromic coatings containing $\mathrm{Ag}\left(\mathrm{Cl}_{1-\mathrm{x}} \mathrm{Br}_{\mathrm{x}}\right)$ microcrystals," Journal of Sol-Gel Science and Technology, vol. 19, no. 1-3, pp. 681-685, 2000.

[4] X. Dong, J. Wang, X. Feng et al., "Fabrication and characterization of nanometer-sized AgCl/PMMA hybrid materials," Modern Applied Science, vol. 2, no. 6, pp. 49-54, 2008.

[5] H. Miyazaki, T. Ota, and I. Yasui, "Design of ITO/transparent resin optically selective transparent composite," Solar Energy Materials and Solar Cells, vol. 79, no. 1, pp. 51-55, 2003.

[6] H. Miyazaki, Y. Teranishi, and T. Ota, "Fabrication of uvopaque and visible-transparent composite film," Solar Energy Materials and Solar Cells, vol. 90, no. 16, pp. 2640-2646, 2006.

[7] H. Suzuki, T. Fujiwara, and H. Miyazaki, "Thermochromic $\mathrm{VO}_{2}$ nano-coated $\mathrm{SiO}_{2}$ nanopowder fabricated by modified chemical solution deposition," Japanese Journal of Applied Physics, vol. 46, pp. 7737-7740, 2007.

[8] J. M. Rincon, H. Marquez, and E. Rivera, "Electron microscopy and EDX-microanalysis of photochromic silver halide glasses of the composition systems $\mathrm{Al}_{2} \mathrm{O}_{3}-\mathrm{B}_{2} \mathrm{O}_{3}-\mathrm{SiO}_{2}$ and $\mathrm{Na}_{2} \mathrm{O}-\mathrm{CaO}-$ $\mathrm{SiO}_{2}$," Journal of Materials Science, vol. 26, no. 5, pp. 1192-1198, 1991. 

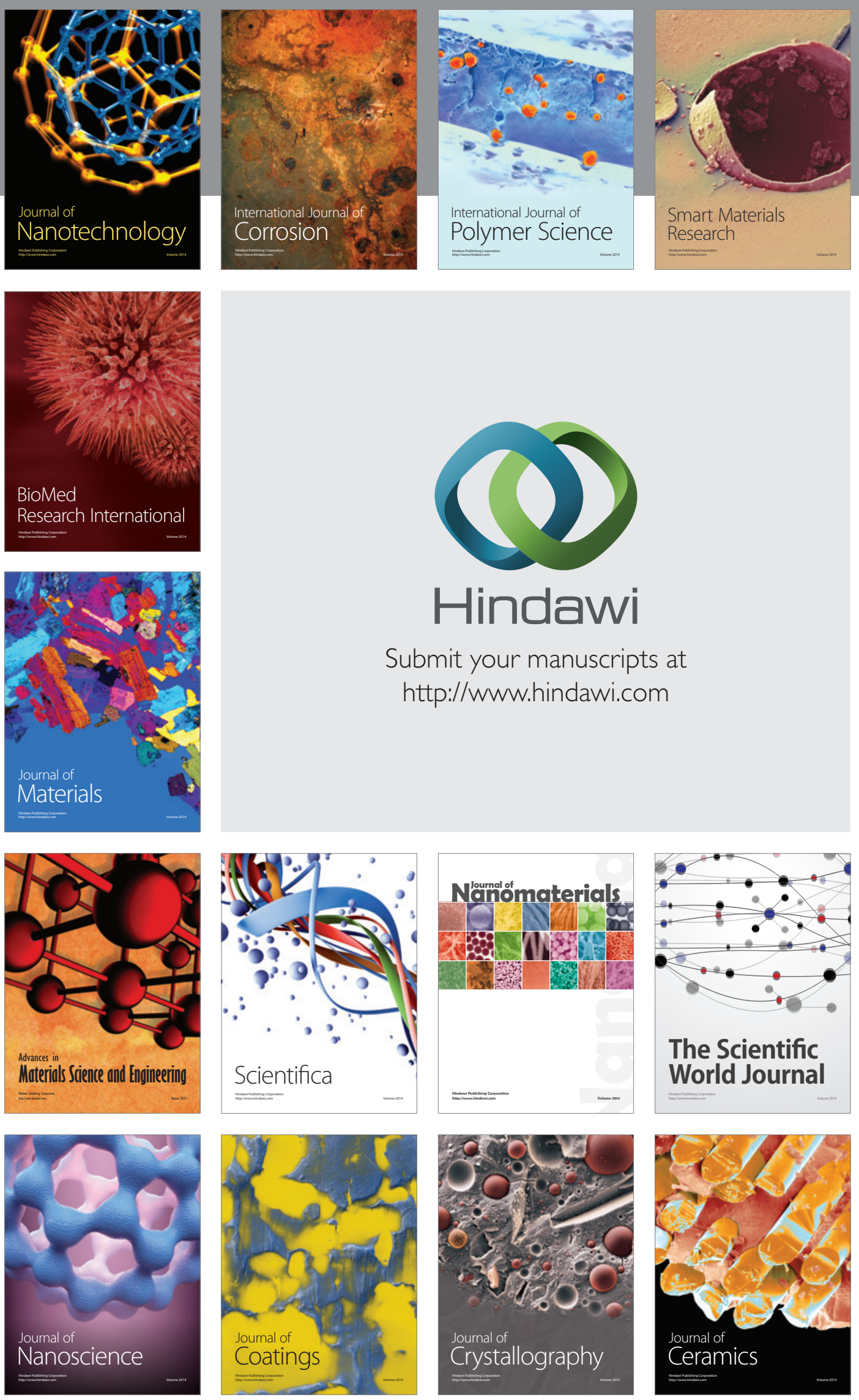

The Scientific World Journal

Submit your manuscripts at

http://www.hindawi.com

\section{World Journal}

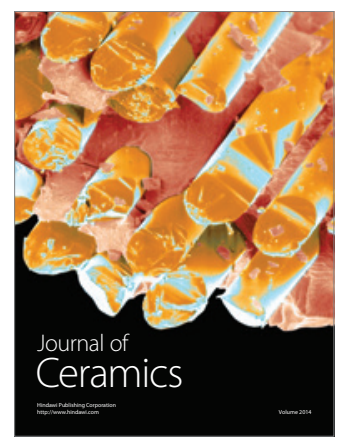

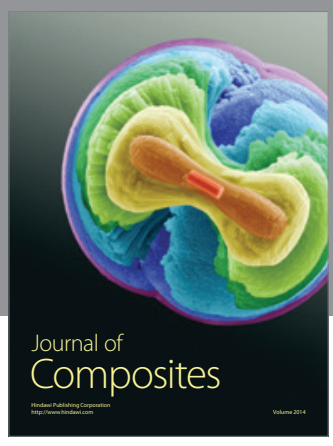
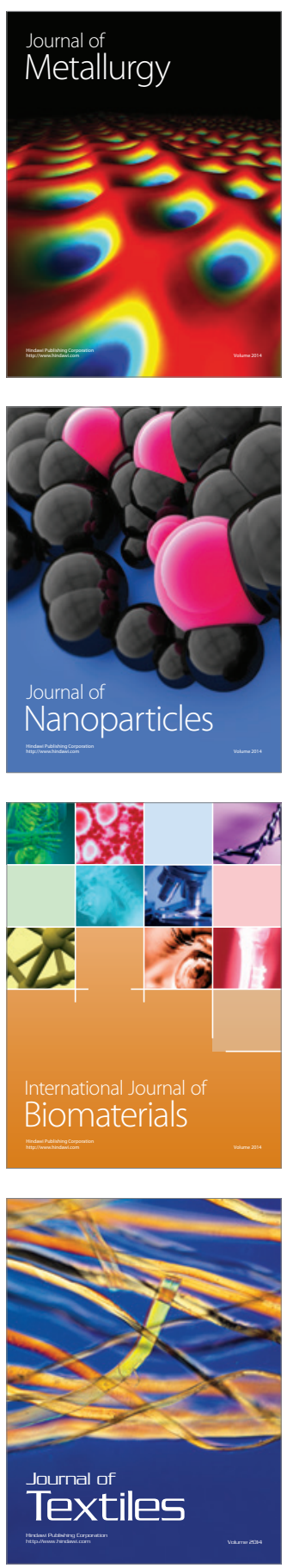